\title{
MOTIVATION IN TIMES OF CHANGE: WOMEN AND EDUCATIONAL PROFESSIONS
}

\author{
Risa R. Simanjuntak \\ English Department, Faculty of Language and Culture, Bina Nusantara University, \\ Jln. Kemanggisan Ilir III No. 45, Kemanggisan/Palmerah, Jakarta Barat 11480, \\ risarsimanjuntak@binus.edu
}

\begin{abstract}
Motivation is a complex issue, in which theorists have tried to approach. Among the classifications are content theories, process theories and integrated theories. Women's world is also complex, where multiple roles involve motivations and lead to different actions. This makes women perfect examples for management in times of change. Article discusses examples of motivation and management in times of change. Subjects of this study primarily are women lecturers and middle managers in educational field of professions. This study also involves qualitative means of data collection with two questions to lead discussions: What has driven you to be lecturers/educators?; What will make you continue become lecturers/educators? Analysis were conducted based on the studies done by Coleman, Ninomiya \& Okato,and. Mwamwenda. It is concluded that women have multiple rather than single factors to motivate them in the profession. It is also agreed that leaders with feminine qualities as well as sensitive to culture are more preferable than those who are absent with them.
\end{abstract}

Keywords: motivation, women, management, leadership

\begin{abstract}
ABSTRAK
Seperti yang telah dijelaskan oleh beberapa pakar, motivasi adalah sebuah isu kompleks yang bisa diklasifikasikan sebagai teori konten, teori proses, dan teori integrasi. Dunia wanita juga kompleks, maksudnya motivasi mendukung mereka berperan ganda yang berdampak pada kegiatan yang berbeda, hal ini yang menjadikan wanita sebagai contoh yang paling baik di dalam manajemen perubahan. Artikel mempresentasikan contoh motivasi dan manajemen perubahan yang dilakukan wanita. Informan penelitian adalah wanita dosen dan wanita manajer di bidang pendidikan. Masalah yang akan dibahas melalui stu kualittaif ini adalah : apakah yang mendorong mereka menjadi dosen ? dan faktor apa yang membuat mereka terus menekuni profesi mereka di bidang pendidikan tersebut. Analisis dilakukan berdasarkan studi terdahulu yang dilakukan oleh Coleman, Ninomiya \& Okato, dan Mwamwenda.Disimpulkan, wanita mempunyai motivasi ganda dalam memilih dan menekuni profesi mereka, dan pimpinan wanita yang sensitif terhadap budaya lebih disukai.
\end{abstract}

Kata kunci: motivasi, wanita, manajemen, kepemimpinan 


\section{INTRODUCTION}

\section{Motivation and Change}

Motivation has been described from simply as 'drive' (Merriam Webster Dictionary, 2003) to 'a complex state with many interrelated aspects’ (Ford, 1992; Riches, 1998; Foskett and Lumby, 2003). It is also generally defined as 'the impetus to take action' (Turner, 1992 in Foskett and Lumby, 2002, p. 76), which ranges from one individual to another. For this reason, continuous study on motivation is important because as articulated by Foskett \& Lumby (2002, p.76). it will 'help influence the direction and strength of the motivation'.

Related to education profession and women, Ford's (1992, p. 248) motivational systems theory (MST) could well be described as the most sensitive to the complexity of the two fields. MST sees a person in its wholeness and in context as its pertinent concept of motivation is as a result of interrelated factors. An illustration is as below (Ford, 1992, p. 249):

Motivation = Goals X Emotions X Personal Agency Beliefs

Figure 1 Motivational Systems Theory

Symbolized by above calculation, Ford wants to underline that human behaviour is 'guided by multiple goals simultaneously' (Ford, 1992, p.249). Though the end results may not be a perfect equation of the participative factors, it is more important to see that each element as interrelated.

There are other theories on motivation discuss issues on profession and people in the working place. One, which gains well acknowledgement, is Herzberg, with his two-factor theory. This theory reveals the existence of satisfiers/motivators and dissatisfiers/hygiene factors. Increasing motivators in the workplace will lead to job satisfaction. Hygiene factors, such as salary or working atmosphere, will influence dissatisfaction. Therefore, Herzberg (1966) argues that it will be irrelevant to motivate workers by increasing salary, because this only reduce the level of dissatisfaction in the work place.

In changing environments, whether members of organizations change places, or whether their course of career and lives are simply developing, leadership and management style are vital. This is because both would incorporate both goals and relationships, which are considered very important to human beings. Foskett and Lumby (2003) underline the importance of managers in education to 'help influence the direction and strength of the motivation' of the staff (p. 76). Thus, women's leadership characteristics are not only unique but vital to the development of education and leadership.

\section{Women and Leadership}

Leadership is an important aspect of educational organization, as people are at heart of education (Early, 2005, Evans, 2003). According to Ford (1992), the role of managers is to 'facilitate, not control, should be the guiding idea in attempts to motivating human' (p.202). Leadership is an important aspect of educational organization, as people are at heart of education (Early, 2005, Evans, 2003). Two of most relevant theories of leadership are contingency theory (Fiedler, 1978; Handy, 1993) and transformational leadership (Bass and Avolio, 1994). 
Heather Eggins' (1997) theory on leadership and gender qualities would be crucial to an organization. Women are stereotyped to have more capabilities in relating to others, while men are perceived as goal-oriented and focus on results rather than relationship. However, Eggins (1997) further states that feminine and masculine qualities in leadership could be posses by both men and women. Developing Gray’s dichotomy, those qualities are displayed below:

Table 1 The Masculine and Feminine Paradigm of Leadership and Management Styles.

Adapted from: Coleman (2000)

\begin{tabular}{ll}
\hline Feminine Paradigm & Masculine Paradigm \\
\hline Caring & Highly regulated \\
Subjective & Objective \\
Tolerant & Disciplined \\
Creative & Conformist \\
Informal & Formal \\
Non-competitive & Competitive \\
Intuitive & Evaluative \\
Aware of individual differences & Normative \\
\hline
\end{tabular}

Nationwide, Indonesian women takes more that $50 \%$ of the whole population out of total population of more than 200 million. Women in Indonesia are deemed to play significant role for the course of the nation. The Central Statistics Bureau (BPS) reports that $21 \%$ of working women are among the high-related paid professionals, or above 1 million rupiahs per month. Although there is no official record on the number of women entering leadership or managerial positions, it is believed that their participations in the work place would be numerically significant.

Riches (1994) stresses the importance of giving feedback, as part of creating the supporting environment for motivation. Feedback and collaborative atmosphere may build the morale of the staff in the organizations (Riches, 1994). Ford (1992) also comments that without feedback, staff may face difficulties in handling the duties when there is no information on how they perform. Feedback could create the sense of 'self-efficacy' (p. 239) in the working place as well as enables professionals to the needs for relevant professional development.

\section{Previous Studies}

Marianne Coleman conducted a wide scope research in 2000 on women secondary head teachers throughout England and Wales. Her study reveals that there are different styles of leadership in both men and women leaders. This underlines what Eggins (1997) has stated earlier, that despite the gender, different qualities could be found in both sexes. Coleman's study also mentions that women tend to use more collaborative approach to leadership than men.

In terms of challenges, women face more than expected loads, which could be considered as not appropriate or good enough (Coleman, 1994, 2000) to have. Other researches also suggest the challenges women face in relation to leadership roles, with the stigma that women leaders are worse than men (Hall, 1996; Ozga, 1993; Oduro, 2003). Accordingly, women sometimes feel insecure in the leadership positions, which at times influence their performance.

Culture also puts challenge in relation to gender in profession. Research in Japan (Ninomiya \& Okato, 1990) and the Transkei in South Africa (Mwamwenda, 1997) show that men receive more respect compared to their women colleagues, resulting to higher job satisfaction of men in education profession. Similarly, in the UK women are considered as having less satisfaction in regard to their influence in the position (Young, 2004). 
This tendency is seen as occurring also in different countries, such as in Malta (Borg and Falzon, 1989), Israel (Kremer-Hayon and Goldstein, 1990; Fresko et al, 1997), and Lesotho (Braimoh and Moletsane, 1998). In developing country such as Indonesia, women's discrimination and inequality also become a major theme in leadership or managerial roles or in professional development in general.

\section{RESEARCH METHODS}

This particular study was conducted throughout the years of 2008 to 2009. Data were taken from the answers to a questionnaire, consisting two sections:

The first, would be the characteristic of leaders according to Gray's Dichotomy:

\begin{tabular}{c|c}
\hline \multicolumn{2}{|c}{ Gray's Dichotomy } \\
\hline Feminine Paradigm & $\begin{array}{c}\text { Masculine } \\
\text { Paradigm }\end{array}$ \\
\hline Caring & Highly regulated \\
Subjective & Objective \\
Tolerant & Disciplined \\
Creative & Conformist \\
Informal & Formal \\
Non-competitive & Competitive \\
Intuitive & Evaluative \\
Aware of individual & Normative \\
differences & \\
\hline
\end{tabular}

The second, comprises of two major questions: what has driven you to be lecturers/educators?; what will make you continue become lecturers/educators?

There would be two institutions mentioned, $\mathrm{X}$ and $\mathrm{Y}$, with $\mathrm{X}$ a private university in Bandung and $\mathrm{Y}$ a similar type of institution based in Jakarta. For the first set of question, there were 18 lecturers, all male, who participated in selecting the characteristics of their female leaders, both Dean of Faculty and Head of Departments. The second set of questions was responded by 35 respondents or informants, 10 of which were newly appointed lecturers. Aside from the set questions, probed inputs were various.

Analysis of the data would be done qualitatively, as Lincoln and Gubba (2003) note that qualitative approach of a research would give a rich and deep understanding of the matters being enquired.

\section{RESULTS AND DISCUSSION}

This particular study takes different occasions on educational institutions with women in leadership positions. Therefore, motivation would be key issues on how professions could be maintained. There would be two institutions mentioned, $\mathrm{X}$ and $\mathrm{Y}$, both are universities, with women as deans of faculties and heads of departments (HoD). Because the discussions would be part of an ongoing research, names are disclosed for technical reasons. The first, $\mathrm{X}$ University is a private institution, situated in Bandung, West Java. Reflecting on Gray's management style, from the observation, female managers in the Faculty of Letters show these styles of leadership: 
Table 2 Management Styles X University as Seen in Comparison with Grays’ Theory

\begin{tabular}{cc}
\hline \multicolumn{2}{c}{ Gray's Dichotomy } \\
\hline Feminine Paradigm & $\begin{array}{c}\text { Masculine } \\
\text { Paradigm }\end{array}$ \\
Caring & Highly regulated \\
Tolerant & Objective \\
Creative & Disciplined \\
Informal & Conformist \\
Non-competitive & Formal \\
Intuitive & Competitive \\
Aware of individual & Evaluative \\
differences & Normative \\
\hline Faculty of Letters, X University's female \\
\multicolumn{2}{c}{ leaders } \\
\multicolumn{3}{c}{ Caring } \\
Objective \\
Disciplined \\
Creative \\
Informal \\
Competitive \\
Intuitive \\
Aware of individual differences
\end{tabular}

There are 5 (five) women leaders in the faculty. Eighteen (18) respondents, fellow lecturers, were asked on their perceptions on the 5 women's leadership. The respondents were asked to tick on the qualities which resemble their leaders. Conclusion on the far-right column is drawn from the biggest numbers or ticks on each of the qualities. From above table, management styles of the dean, deputy dean and 3 (three) HoDs show combination of both feminine and masculine characteristics.

From an interview with one of the HoDs, it was mentioned that being good leaders means that there should be a strict line between friendship and professionalism. Another HoD believed that objectivity could still be sustained even though the approach to colleagues was informal.

Lecturers and staff under the management in X University implied that things were better under the female managers. Before, two people of the management were males, including the Dean. Both men were rarely seen in the office and were not communicating with people under them. When the new female dean was appointed they recalled that things were more in order. There were more people coming to work on-time, and less substitute classes because lecturers were absent. One reason for this was that the dean promoted week-ends for family by talking over young-single lecturers to take Saturday classes. In addition to this, she would talk over changes or new responsibilities by meetings or phone calls. In the discussion she would explain about what changes/new responsibilities were, why they were needed, how they were possibly be carried out and what they staff though about these.

These were similar to Ford's (1992) theory on goals and facilitation from a leader. The dean was further commented that in order to get the maximum result, she would need everyone to contribute. The leader also made sure that the job was doable and that the task met everyone's expectations on goals. The second is Y University, another private institution in Jakarta. The English Department in the university has 89 active lecturers, including a female HoD. The composition of the lecturing body is shown in the table below: 
Table 3 Lecturers' Composition at English Department, University Y

\begin{tabular}{cccc}
\hline Lecturers & Married & Single & Total \\
\hline Male & 27 & 11 & 38 \\
Female & 40 & 11 & 51 \\
Total & 67 & 22 & 89 \\
\hline
\end{tabular}

In the beginning of each of teaching appointment there would be an interview session. One of the questions asked was: What drives you to be a lecturer? Mostly candidates would answer: to gain more knowledge, or to keep on studying. Out of the 35 lecturers who responded to the questions:

1. What has driven you to be lecturers/educators?

2. What will make you continue become lecturers/educators?

There were various responses:

Table 4 Responses to Questionnaire

\begin{tabular}{ll}
\multicolumn{1}{c}{ Question 1 } & \multicolumn{1}{c}{ Question 2 } \\
\hline To broaden horizons & Experiences gained \\
Individual passion & Knowledge gained \\
Profession fitting to the degree & Environment (collegial) \\
Love literature and culture & Financial reasons \\
To give something back to the society & To pursue higher degree \\
Love to teach & Support from the institution \\
Felt called into the profession & Keep sharpening the mind \\
\hline
\end{tabular}

Meanwhile, one respondent, a married woman with two children, had her own reason to be in the profession. Her motive to become a lecturer in the English Department was to 'sound her intellectual minds'. She admitted that being a full-time mother and wife ignite her other dream of channeling her passion on literature, leaving her with good feelings of existence (Ford, 1992). This was also similar to previous studies (Coleman, 2000; Eggins, 1997).

In the issue of change, some lecturers have more 'drives' after getting married. These drives were found in 3 (three) male lecturers in X university. When assigned with new classes in beginning of the semester, requests were made on adding more teaching sessions. When they mentioned their situations, several issues were raised as what drives them to have more sessions in a week of lecture sessions. Lecturing gave way for more intellectual development, and it was also mentioned that they were driven by the needs to meet their family's financial demands. Naturally, they expressed their expectations the leader of the department to be sensitive to this matter.

The expectations of male subordinates in university $\mathrm{X}$ to their female leader were partially stereotyped. They expected that their leader would be caring, sensitive and subjectively support their condition. In reality, although the HoD comprehended the situation, lecturing appointments were made dominantly by their performances in the past semesters. The university has applied a survey-based evaluation on the performance of its lecturers. This survey, combined with operational-related evaluation is strongly suggested to be the ground for judgment. As a result the HoD acted more objectively rather than subjectively as expected by the lecturers. To this reality, with the large numbers of lecturers to be served, leadership in this situation has been found challenging. 
The second question posited: "What will make you continue become lecturers/educators?" was receiving similar answers. The respondents' answers in Y University were a combination of: actualization, knowledge-gain, and reality demands for jobs and income. In fact, the female HoD said that she had to juggle between meeting the superiors' target for better service in the classroom with answering lecturers' needs and expectations. At times, she admitted that she took side on the lecturers, believing that people matters most, more important than goals of organization.

\section{CONCLUSION}

There seem to be more strains in the conclusion on motivation. Different examples in this study show the importance not to narrow-down motivation to a definition. Rather it is more important to take account the contexts and situation in which people may best act or perform in their profession. Women educators, as well as leaders, turn to be non-stereotypical. Their actions are determined more on the situation rather than the qualities they are said to acquire. They may have combination of factors, which motivate them. On the other hand, women leaders have had more challenges due to the gender-related expectations. It is shown from the study that women posses qualities of the masculine paradigm as well as the feminine. Those who are sensitive to context and cultures are more expected than those who are without.

\section{REFERENCES}

Borg, M. and Falzon, J. (1989) 'Stress and Job Satisfaction among Primary School Teachers in Malta', Educational Review, 41 (3), pp.271-279.

Braimoh, B. and Moletsane, R. (1998) 'Teachers' Job Satisfaction as a Factor of Academic Achievement in Lesotho Schools, Education Today, 48 (2), pp.49-56.

Coleman, M. (1994). 'Women in Educational Management' in Bush, T. \& West-Burnham, J. The Principles of Educational Management. Harlow: Longman.

Coleman, M. (2000) 'The Female Secondary Headteacher in England and Wales: Leadership and Management Styles', Educational Research, 42 (1), pp. 13-27.

Eggins, H. (ed.) (1997) Women as Leaders and Managers in Higher Education. London: Taylor and Francis

Evans, L. (2003) 'Leadership role: morale, job satisfaction and motivation', in Kydd, L. et al (eds.) Leading People and Teams in Education, London: Paul Chapman.

Ford, M. (1992) Motivating Humans, Goals, Emotions and Personal Agency Beliefs, Newbury Park: Sage.

Foskett, N. and Lumby, J. (2003) Leading and Managing Education: International Dimensions, London: Paul Chapman.

Fresko, B., Kfir, D. and Nasser, F. (1997) 'Predicting Teacher Commitment', Teaching and Teacher Education, 13 (4), pp.429-438.

Fullan, M. (2001) Leading in a Culture of Change. San Fransisco, CA: Jossey-Bass. 
Gray, H.L. (1993), 'Gender Issues in Management Training' in Ozga, J. (ed.) Women in Educational Management, Bristol, PA: Open University Press.

Hall, V. (1996). Dancing on the Ceiling: A Study of Women Managers in Education. London: Paul Chapman.

Herzberg, F. (1966) Work and the Nature of Man, Cleveland: World.

Kremer-Hayon, L. and Goldstein, Z. (1990) 'The inner world of Israeli secondary school teachers: work centrality, job satisfaction and stress’, Comparative Education, 20 (2/3), pp.285-298.

Mwamwenda, T. (1997) 'Teacher Gender Differences in Job Satisfaction in Transkei', Research in Education, 58, pp.75-77.

Ninomiya, A. and Okato, T. (1990) 'A Critical Analysis of Job-Satisfied Teachers in Japan', Comparative Education, 26 (2/3), pp.249-258.

Oduro, G. K. T. and Macbeath, J. (2003). 'Traditions and Tensions in Leadership: The Ghanaian Experience'. Cambridge Journal of Education, 33(3), pp. 441-455.

Ozga, J. (1993). Women in Educational Management. Bristol, PA: Open University Press.

Riches, C. (1994) 'Motivation', in Bush, T. and West-Burnham, J. (eds.) The Principles of Educational Management, Harlow: Longman.

Young, P. (2004). 'Leadership and Gender in Higher Education: a Case Study'. Journal of Further and Higher Education, (28) 1, pp. 95-106. 